\title{
The Distribution of Safety within a State: Seismic Evaluation of School Buildings
}

\author{
Hee-Chan Cho*
}

\begin{abstract}
This study examines the factors that influence human vulnerability to natural disasters by focusing on the seismic evaluation of school buildings in Korea. Since natural disasters such as an earthquake often do not take people's lives directly, but rather indirectly through the destruction of physical structures, seismic reinforcement of school buildings may reduce the vulnerability of their occupants by strengthening structures to withstand such disasters. Disaster mitigation measures are implemented within a state; however, little is known about how they are distributed when the physical properties of structures are taken into account. This paper analyzes a panel data based on the structural properties of school buildings in eight different provinces between 2011 and 2015 using a logistic regression model. The results show that factors identified in cross-country studies, such as economic capacity and political factors, still have influence on earthquake preparedness at the state level, even when the physical properties of structures or technical factors are considered.
\end{abstract}

Keywords: human vulnerability; natural hazards; seismic evaluation; school buildings

\section{INTRODUCTION}

Natural hazards "only turn into disasters when societies are exposed and not resilient to fully absorb" the impact of natural forces (Neumayer, Plümper, \& Barthel, 2014, p. 9; Schwab, Eschelbach, \& Brower, 2007; Paul, 2011). The impact of natural disasters, therefore, varies across states, since the ability to manage natural disasters is associated with the level of economic development and political institutions, as numerous studies suggest (Kahn, 2005; Anbarci, Escaleras, \& Register, 2005; Escaleras, Anbarci, \& Register, 2007; Keefer, Neumayer, \& Plümper, 2011;

\footnotetext{
* Hee-Chan Cho is a Ph.D. student in the Graduate School of Public Administration, Seoul National University, Korea. Email: heechan@snu.ac.kr.
}

Manuscript received November 29, 2017; out for review December 18, 2017; review completed March 2, 2018; accepted March 7, 2018.

The Korean Journal of Policy Studies, Vol. 33, No. 1 (2018), pp. 1-32.

(C) 2018 by the GSPA, Seoul National University 
Lin, 2014; Neumayer et al., 2014). However, the level of preparedness for the unpredictable may not only vary across states but also within a state, and such variance may arise from the different adaptions of mitigation measures within a state where the economic conditions and institutions are relatively similar.

This study examines the factors that influence human vulnerability to natural disasters within a state by focusing on the seismic evaluation of school buildings in Korea. Seismic reinforcement of school buildings reduces the vulnerability of their occupants by strengthening structures to withstand disasters, since people are exposed to structural failures during earthquakes. Considering the importance of school buildings to local populations during and after a natural disaster (Bellet, 2004), the level of human vulnerability within a state can be assessed in part by examining their earthquake preparedness.

The physical properties of structures have been overlooked in cross-country studies because they have assumed that such properties are incorporated into economic development. Since disaster mitigation measures are enforced by a state, focusing on the state level may reveal the role physical properties of existing structures play on the adaptation of mitigation measures and suggest implications that the physical properties of structures have on policy. Even if risk is inherent in a society, safety measures are deliberately distributed by the society to reduce their vulnerability. Identifying factors that affect decisions related to disasters that have a low probability of occurring but would be catastrophic if overlooked will help policy makers grasp the underlying process of disaster mitigation and develop strategies to prevent the worst.

\section{HUMAN VULNERABILITY AND ECONOMIC CAPACITY}

Human vulnerability is, according to United Nations Office for Disaster Risk Reduction (2004), "the conditions determined by physical, social, economic and environmental factors or processes which increase the susceptibility of a community to the impact of hazards." The level of economic development is one of the critical determinants of shaping human vulnerability. Kahn (2005) has shown that although developed countries do not experience fewer natural disasters than developing countries, they suffer fewer casualties. Economic development provides a shield against unpredictable natural phenomenon.

A state may create "infrastructural power" (Mann, 1986), such as transportation, communication, and emergency response systems, which are essential for emergency response and evaluation when disaster hits (Jha, Barenstein, Phelps, Pittet, \& Sena, 2010; Lin, 2014). Economic development, a capacity to provide infrastructur- 
al power, improves physical protection for individuals, as well as information and transportation grids for the public, thereby "reduc[ing] human vulnerability in multiple dimensions" (Lin, 2014, p. 1274; Deaton, 2003).

The lack of economic capacity constrains implementation of a sufficient number of disaster mitigation measures. Implementing such safety measures is costly, and "the degree to which [individuals] benefit from and are able to comply with and employ their own established safety standards depends on the level of economic development." (Skidmore \& Toya, 2013, p. 45; Tselios \& Tompkins, 2017, p. 6). Reaching a consensus to commit to seemingly unnecessary spending is even more difficult under budget constraints. Anbarci, Escaleras, and Register (2005) claim that failure of collective action with respect to disaster preparation is due to insufficient per capita income to purchase the necessary resources as well as conflicts over the distribution of the relative burden of the costs of such resources.

Besides greater economic and physical capabilities, individuals in developed countries have more economically motivated than those in less developed countries to invest in mitigation measures to save lives and valued properties. The political elites in developed countries have an incentive to invest in disaster mitigation measures because natural disasters may imperil the stability of the ruling party or the government itself (Kahn, 2005; Lin, 2014) and also because citizens demand that their communities and regions be made safer. The elected officials in developing countries are more likely to be myopic regarding disaster preparedness (Lin, 2014), since "the ex ante opportunity cost" of implementing disaster mitigation measures can be too high (Keefer et al., 2011), and they also may not have sufficient information to develop adequate mitigation measures. They could also be more inclined to prioritize their political survival (Bueno de Mesquita, Smith, Siverson, \& Morrow, 2003; Keefer et al., 2011).

Even if elected officials are responsive to the demands of citizens, reinforcing vulnerable school buildings is costly, and it might not be as efficient as investing in other safety measures. Each school district needs to make decisions about how to provide safety within their jurisdiction, and economic conditions may work to constrain their options. This state of affairs informs the first hypothesis of this paper: regions that are relatively affluent within a state are less vulnerable to natural disasters.

\section{HUMAN VULNERABILITY AND POLITICAL INSTITUTIONS}

\section{Effects of Democracy}

Institutions are a type of measure that protect the population from natural disaster 
fatalities. Democracy in the form of popular demand may reshape the structure of public spending in favor of more safety provisions. Several studies consider the extent to which politics affect human vulnerability and the resilience of society throughout the disaster cycle, from pre-disaster mitigation to post-disaster rehabilitation (Aldrich, 2012; Brooks, Adger, \& Kelly, 2005; Jones \& Murphy, 2009; Wisner, Blaikie, Cannon, \& Davis, 2004; Lin, 2014).

Politicians may increase public spending on disaster preparedness in order to maximize their likelihood of being reelected, and the effect of higher spending is a reduction in the number of fatalities during natural disasters in democratic states (Wildavsky, 1988; Kahn, 2005). Since elected officials are vote-maximizing rational actors, they are "attentive to the political implications on electoral outcomes of their decisions regarding service distribution" (Lee, 1994, p. 88). Lin (2014) has also found that while controlling for the indicators of natural hazards and socioeconomic vulnerability, democracy is still associated with a lower death toll from natural disasters. Moreover, he shows that the level of state capacity and the extent of its interactions with democracy are linked to the number of people affected by disasters. Garrett and Sobel (2003) show that the amount of aid provided by the U.S. Federal Emergency Management Administration (FEMA) to a disaster area is "highly correlated with the political importance of a particular state to the sitting president and to the state's congressional representation on FEMA oversight committees" (Escaleras et al., 2007, p. 10). These findings foreground the role of citizens in demanding services (Cingranelli, 1981; Marwell, 2004), elected officials in acting to pursue their electoral interests (Pallas \& Jennings, 2010), and bureaucrats in implementing policy (Lee, 1994; Lin, 2014).

In contrast, other disaster mitigation studies, emphasizing the unpredictable nature of natural disasters, underscore the extent to which elected officials and citizens are myopic when it comes to disaster preparation. The shortsightedness of voters and politicians may lead them to prefer relief spending (Cole, Healy, \& Werker, 2012), resulting in a lack of preparedness against disasters (Healy \& Malhorta, 2009). Elected officials know that government spending on disaster mitigation does not have much visibility. Besides, individuals tend to neglect (or ignore) unpredictable threats; elected officials are thus less likely to prepare for unpredictable disasters like earthquakes (Neumayer et al., 2014). Individuals tend to be more attentive to prevention and mitigation measures after a disaster, as Gasper and Reeves (2011) show. According to this view, even if elected officials and individuals are aware that a long-term investment is needed to secure safety for all, short-term incentive structures mean such an investment is not likely to be made.

The unpredictable nature of earthquakes may aggravate the shortsightedness of 
individuals on the need for mitigation measures; however, even if elected officials and citizens are myopic on this front, general safety issues are still more likely to be addressed by the government in more politically active regions. Moreover, even if a state has not experienced any natural disaster, if neighboring states have suffered from severe hazards, proactive individuals may demand comprehensive safety measures. Since elected officials tend to be more responsive to voters' preferences than to those of nonvoters (Martin, 2003; Griffin \& Newman, 2005), politically active regions with proactive individuals may have more safety resources allocated to them, which grounds the second hypotheses: politically active regions within a state are less likely to be vulnerable to natural disasters.

\section{Other Socioeconomic Factors}

Some studies explain the variation in fatalities by the age of regimes (Keefer et al., 2011). They show that institutionalized societies are more likely to invest in disaster mitigation measures by using the age of regimes as an indicator of the degree to which the regimes are institutionalized regardless of the types of regimes.

Tselios and Tompkins (2017) show that states with greater local representation are more likely undertake disaster preparedness. They also argue that disaster preparedness and political decentralization vary with the dominant political orientation of a state, since the political strategies that the left and the right use with local authorities and central government differ. In the wake of decentralization, the level of economic development may play a role in preparedness within a state. Prosperous regions not only have enough resources but also have "political leverage to negotiate with the central government" (Tselios \& Tompkins, 2017, p. 6; Rodriguez-Pose \& Ezcurra, 2011). Several studies associate the level of inequality in a state with preparation for natural disasters. Anbarci, Escaleras, and Register (2005) show that the level of inequality is negatively associated with the likelihood of a society to reach an agreement on the distribution of the economic burden of disaster preparation, the result of which is that "the rich self-insure against disasters, whereas the poor are left to mercy" (Lin, 2014, p. 1270).

Corrupted states are associated with fatalities. The choices of individuals can vary not only according to the nature of the political system itself but also to the level of public corruption in a state (Delavallade, 2006). Escaleras, Anbarci, and Register (2007) report that public sector corruption is positively related to casualties associated with earthquakes. Kahn (2005) also mentions that government corruption may result in a higher death toll due to the lack of regulations and enforcements. A transparent bureaucracy may reduce the principle-agent problem that results in polit- 
ical corruption and thus may reduce the number of earthquake fatalities (Escaleras et al., 2007). This leads to the third hypothesis: regions where the level of corruption is relatively low within a state are less likely to be vulnerable to natural disasters.

Furthermore, if high economic capacity is a necessary condition for implementing effective mitigation measures, political factors may affect the amount of resources allocated for the safety of a society and have an effect on the role of economic capacity in the distribution of mitigation measures, which leads to the fourth hypothesis : political factors increase the effect regional economic capacity has on reducing human vulnerability to natural disasters.

\section{HUMAN VULNERABILITY AND TECHNICAL FACTORS}

The fact that the potentially devastating effects of earthquakes can be reduced by seismically designed structures and reinforcements indicates that the physical and technical aspects of infrastructure affect human vulnerability. A physical structure may provide safety, but an unreliable physical structure may also make occupants even more vulnerable. While "earthquakes are natural phenomena beyond the reach of humankind" (Anbarci et al., 2005,1907), they rarely affect the entire state but tend rather strike a local community or a region (Escaleras \& Register, 2012); therefore, collective action to reinforce weak structures in vulnerable areas may reduce human vulnerability to the effects of earthquakes.

The level of collective action and inaction with respect to safety measures can depend on the physical state of infrastructure. Economic capacity may govern the overall state of the infrastructure that deals with natural disasters, and political institutions make it possible for individuals to demand natural disaster preparation. However, such demands could be governed by individuals' belief that the physical infrastructure of their society is old and therefore unsafe, which is the basis of the fifth hypothesis: regions within a state whose infrastructure is relatively more vulnerable are more likely to be better prepared for natural disasters.

Moreover, unreliable structures, in urgent need of improvements, may garner more resources, increasing the effect of economic capacity on the likelihood of reinforcement of such structures, which leads to the sixth hypothesis: technical factors increase the effect regional economic capacity has on reducing human vulnerability to natural disasters. 


\section{THE SEISMIC EVALUATION OF SCHOOL BUILDINGS IN KOREA}

School buildings play a vital role in contingency plans. Most school buildings contain large classrooms, restrooms, and food service capabilities, and when they are well constructed, they may function as emergency shelters for the local population during and after a natural disaster (Ballet, 2004). Areas in which school buildings remain intact during and after natural disasters are less likely to be vulnerable. However, the importance of school buildings is often overlooked (Shaw \& Kobayashi, 2001), and as one study refers to South Korea as a dangerous society (Lee, 2015, p. 125), the Korean government may also have underestimated their importance. According to the Ministry of Public Safety and Security (2015a), 42.4\% of public buildings and structures in Korea were seismic designed or retrofitted as of October 2015 , while only $22.8 \%$ of school buildings were seismically sound. Table 1 shows the current state of earthquake preparedness of school buildings. Since most of the school buildings were built before 2005, the year in which the building code that requires newly constructed school buildings to be seismic designed was implemented, many of these buildings do not meet the standard set by the building code.

Table 1. School Buildings in Regions of Korea

\begin{tabular}{l|r|r|r|r}
\hline \multicolumn{1}{c|}{ Region } & Total & $\begin{array}{c}\text { Buildings Subject to } \\
\text { Building Code }\end{array}$ & $\begin{array}{c}\text { Earthquake- } \\
\text { Resistant Buildings }\end{array}$ & \multicolumn{1}{c}{$\begin{array}{c}\text { Vulnerable } \\
\text { Buildings }\end{array}$} \\
\hline Seoul & 6,016 & $3,451(57.4 \%)$ & $917(26.6 \%)$ & $2,534(73.4 \%)$ \\
Busan & 3,155 & $1,404(44.5 \%)$ & $407(29.0 \%)$ & $997(71.0 \%)$ \\
Daegu & 1,795 & $1,129(62.9 \%)$ & $345(30.6 \%)$ & $784(69.4 \%)$ \\
Incheon & 2,387 & $1,312(55.0 \%)$ & $319(24.3 \%)$ & $993(75.7 \%)$ \\
Gwangju & 1,021 & $929(91.0 \%)$ & $204(22.0 \%)$ & $725(78.0 \%)$ \\
Daejeon & 1,714 & $653(38.1 \%)$ & $177(27.1 \%)$ & $476(72.9 \%)$ \\
Ulsan & 1,015 & $585(57.6 \%)$ & $216(36.9 \%)$ & $369(63.1 \%)$ \\
Sejong & 222 & $132(59.5 \%)$ & $91(68.9 \%)$ & $41(31.1 \%)$ \\
Gyeonggi & 7,903 & $4,920(62.3 \%)$ & $1,585(32.2 \%)$ & $3,335(67.8 \%)$ \\
Gangwon & 4,928 & $1,984(40.3 \%)$ & $402(20.3 \%)$ & $582(29.3 \%)$ \\
Chungbuk & 2,988 & $1,530(51.2 \%)$ & $360(23.5 \%)$ & $1,170(76.5 \%)$ \\
Chungnam & 3,803 & $2,107(55.4 \%)$ & $455(21.6 \%)$ & $1,652(78.4 \%)$ \\
Jeonbuk & 4,985 & $2,493(50.0 \%)$ & $421(16.9 \%)$ & $2,072(83.1 \%)$ \\
Jeonnam & 8,139 & $3,176(39.0 \%)$ & $599(18.9 \%)$ & $2,577(81.1 \%)$ \\
Gyeongbuk & 5,560 & $2,657(47.8 \%)$ & $477(18.0 \%)$ & $2,180(82.0 \%)$ \\
Gyeongnam & 5,221 & $2,752(52.7 \%)$ & $575(20.9 \%)$ & $2,177(79.1 \%)$ \\
Jeju & 1,007 & $598(59.4 \%)$ & $84(14.0 \%)$ & $514(86.0 \%)$ \\
\hline Total & 61,670 & $31,797(51.6 \%)$ & $7,553(23.8 \%)$ & $24,244(76.2 \%)$ \\
\hline
\end{tabular}

Sources: Ministry of Education (2016); Gyeonggido Office of Education (2017) 
To protect lives and properties of people and minimize socioeconomic damage caused by earthquakes, the Korean government has required that public facilities must have a seismic design. However, this seismic reinforcement policy has been seen as a reaction to earthquakes in neighboring countries and therefore as passive rather than proactive (Jung, 2012). After the 2008 Sichuan earthquake which left countless students the victims of poorly constructed school buildings, the Ministry of Education, Science and Technology announced plans for seismic design of school buildings and introduced the Earthquake Recovery Plans Act (Act No. 9636, 22 April 2009) - the first act to call for seismic reinforcement of existing school buildings (Ministry of Public Safety and Security, 2015b).

\section{Seismic Reinforcement and the Decision-Making Process}

The seismic reinforcement procedure as outlined by the Ministry of Education's 2014 National Security Management Implementation Plan (MOE, 2013; 2015) has nine steps, from preliminary evaluation to the construction and implementation of seismic reinforcement. A master plan for the seismic reinforcement of existing public facilities that was developed in 2009 by the National Emergency Management Agency emphasizes the importance of preliminary evaluation in prioritizing school buildings at risk. Once a school building is diagnosed unsafe, the seismic retrofit process is undertaken.

Since there are more than 20,000 school buildings in need of reinforcement in Korea, a preliminary evaluation is necessary to make the process more efficient. A preliminary evaluation does not include a technical evaluation, which can be highly technical, time consuming, and costly; however, it does include an assessment of socioeconomic factors and the historical importance of the building, geological information about the area, and basic structural information such as structure type and the year of construction.

The Ministry of Education oversees the seismic reinforcement of school buildings according to the master plan; however, the local education office carries out the process. The Ministry of Education initially funded a pilot school building seismic reinforcement project in 2011 and directed the local education offices to use the local education budget to reinforce the remaining buildings (Jung, 2013). The Ministry of Education (2015) also directed the education offices to use educational environment improvement expenses from the local education budget to carry out the reinforcements. The Gyeonggido Office of Education (2017) states that each regional education office set the order in which the school buildings would be reinforced based on the general criteria provided by the Ministry of Education. Article 6 of Act 
on the Prevention of and Compensation for Accidents at School (Act No. 8852, 22 February 2008) also requires superintendents to implement safety inspections on school facilities, pursuant to the provisions of article 22 of the Framework Act on the Management of Disasters and Safety (Act No. 14553, 17 January 2017), which sets the guidelines for the formulation of master plans for national disaster and safety management. The master plan outlines the criteria and assigns them weights, which enables assessors to identify school buildings that will be more vulnerable in the event of a disaster. The categories and their weights are shown in table 2. The master plan, however, does not assign weights to every factor but leaves the details to each public contractor.

Table 2. Categories and Weights Considered in Preliminary Evaluations of Buildings

\begin{tabular}{|c|c|c|}
\hline \multicolumn{2}{|l|}{ Categories } & \multirow{2}{*}{$\begin{array}{c}\text { Weights (Points) } \\
1\end{array}$} \\
\hline \multirow{4}{*}{ Number of Floors } & $1-2$ & \\
\hline & $3-5$ & 2 \\
\hline & $6-9$ & 3 \\
\hline & more than 10 & 4 \\
\hline \multirow{4}{*}{$\begin{array}{l}\text { Gross Floor Area } \\
\text { (Square Meters) }\end{array}$} & less than 1,000 & 1 \\
\hline & $1,000-5,000$ & 2 \\
\hline & $5,000-10,000$ & 3 \\
\hline & $10,000-$ & 4 \\
\hline \multirow{2}{*}{ Seismic Zone } & seismic zone 1 & 2 \\
\hline & seismic zone 2 & 1 \\
\hline \multirow{5}{*}{ Building Type } & classroom & 3 \\
\hline & dormitory & 3 \\
\hline & auditorium & 2 \\
\hline & gymnasium & 2 \\
\hline & cafeteria & 1 \\
\hline \multirow{6}{*}{ Structural Type } & masonry & 3 \\
\hline & reinforced concrete & 1 \\
\hline & steel framed & 1 \\
\hline & steel-reinforced concrete & 1 \\
\hline & light-weight steel framed & 1 \\
\hline & other & 1 \\
\hline
\end{tabular}

Source: National Emergency Management Agency (2009) 
Seismic reinforcement plans for school buildings in six different school districts were examined to see how consistent they were. The criteria and the weight of each criterion utilized by the Gyeonggi Yongin Office of Education (2016) are shown in table 3 as an example. Although each school district assigns different weights to each category, the categories they use are similar across the board. Most consider building type, prioritizing classrooms (such as the Incheon Metropolitan Office of Education [2015]), but others give more weight on dormitories and gymnasiums (such as the Busan Metropolitan Office of Education [2016]).

Table 3. Categories and Weights Considered by the Gyeonggi Office of Education

\begin{tabular}{l|c}
\hline \multicolumn{1}{c|}{ Categories } & Points \\
\hline Number of Floors & 9 \\
Number of Years since Built & 4 \\
Gross Floor Area (Square Meters) & 3 \\
School Grade & 4 \\
Metropolitan & 2 \\
Safety Rating & 2 \\
Shape of Structure & 2 \\
Pilotis & 2 \\
Basement & 2 \\
\hline
\end{tabular}

Source: Gyeonggi Yongin Office of Education (2016)

Many also consider school grade, prioritizing elementary school over middle and high school buildings. The Gyeonggido Office of Education (2017) states that since managing the academic calendar for high school is harder than managing that of elementary or middle school due to the college entrance exam, elementary school buildings are prioritized. The use of such criteria shows that the physical capabilities of students are considered (Seoul Metropolitan Office of Education, 2015a). According to the Korean Institute of Educational Environment (2010), Hashima City in Gifu, Japan, allocates more points to elementary school buildings because middle and high school students are more agile during evacuation and are able to perceive danger more quickly than elementary school students.

Most school districts also consider budgeting and scheduling efficiencies (Gyeonggi Goyang Office of Education, 2016), giving more weight on school buildings that are more likely to be utilized for more than 20 years and school buildings that are already in the midst of ongoing construction projects (Gyeongsangnamdo Office 
of Education, 2016). For similar reasons, the Chungchungnamdo Office of Education prioritizes school buildings less than 40 years old with more than three stories. Some also consider the extent of damage that will result on failure, prioritizing school buildings in metropolitan area (Gyeonggido Office of Education, 2017). The Gyeonggido Office of Education (2015) prioritizes school buildings in districts have not been previously reinforced in order to ensure the fair distribution of seismic mitigation measures.

Table 4. Initial School Buildings Chosen for Seismic Reinforcement by the Gyeonggido Office of Education

\begin{tabular}{|c|c|c|c|c|c|}
\hline $\begin{array}{l}\text { School } \\
\text { Grade }\end{array}$ & $\begin{array}{l}\text { Type of } \\
\text { School }\end{array}$ & Name of School & Building Type & Points & $\begin{array}{c}\text { Cost } \\
(\$ 1,000)\end{array}$ \\
\hline \multirow{13}{*}{ Elementary } & \multirow{13}{*}{ Public } & G.O. & classroom & 27 & 807,813 \\
\hline & & G.D. & classroom & 27 & 802,872 \\
\hline & & D.M. & classroom & 27 & 711,018 \\
\hline & & D.C. & classroom & 27 & 726,732 \\
\hline & & S.C. & classroom & 27 & 791,532 \\
\hline & & T.W. & classroom & 27 & 707,616 \\
\hline & & D.J. & classroom & 26 & 796,392 \\
\hline & & S.S. & classroom & 26 & 734,751 \\
\hline & & S.I. & classroom & 26 & 722,763 \\
\hline & & Y.B. & classroom & 26 & 613,170 \\
\hline & & Y.M. & classroom & 26 & 696,357 \\
\hline & & S.C. & classroom & 26 & 768,204 \\
\hline & & C.G. & classroom & 26 & 755,649 \\
\hline \multirow{2}{*}{ Middle } & \multirow{2}{*}{ Public } & N.G. & classroom & 26 & 806,598 \\
\hline & & E.D. & classroom & 26 & 744,684 \\
\hline Total & & 15 & & & $11,216,151$ \\
\hline
\end{tabular}

Source: Gyeonggi Yongin Office of Education (2016)

Although many school districts use the same criteria in their preliminary evaluations of school buildings, these criteria are not necessarily sufficient for deciding the order in which to carry out seismic reinforcement of school buildings. As shown in tables 2 and 3, there is not much variance between the points given to each school building, since most school buildings in Korea are similar in shape and size. Table 4 shows the points assigned to the first 15 schools buildings selected for reinforcement after the preliminary evaluation in the Gyeonggi Yongin school district. The Gyeonggi Yongin Office of Education finalized the order of school buildings based 
on the primary selection by the Gyeonggido Office of Education. A committee comprised of bureaucrats from the office and a school principal decides on the order of seismic reinforcement. The committee can add or deduct up to five adjustment points on consideration of the academic calendar, the opinion of the school principal, and whether there is ongoing remodeling or expansion (Gyeonggi Yongin Office of Education, 2016).

\section{DATA AND MEASURES}

\section{Data}

Data was collected in a panel form, from 2011 to 2015, and sorted by individual school building. Information regarding the physical properties of each school building and whether it had been seismically evaluated was requested from every education office in Korea. As mentioned, each education office manages school environment and safety and is responsible for seismic evaluation and reinforcement of vulnerable school buildings. Every office except the Busan Metropolitan City Office of Education and Ulsan Metropolitan Office of Education responded. ${ }^{1}$

A number of education offices failed the provide a key variable: the year when seismic evaluation was carried out. After compilation of each data set, only the data for schools in Seoul, Gyunggi, Gangwon, Chungbuk, Chungnam, Jeonbuk, Jeonnam, and Gyungbuk area was found to be complete. Although schools in metropolitan areas were mostly dropped out, the data set includes schools dispersed throughout Korea, covering most of the regions.

\section{Measures}

Economic capacity is measured by utilizing an environmental improvement expenditure ratio, the local education budget, and the degree of fiscal independence. The main budget for seismic reinforcement of school buildings comes from the

1. The Busan Metropolitan City Office of Education refused to provide the requested information on the grounds that it might cause a disruption in its procedure; it was concerned that because seismic evaluation and reinforcement of school buildings are carried out using the criteria it set, disclosing such information could increase complaints and demands from parents, which could delay the whole process. The Ulsan Metropolitan Office of Education promised to disclose the information in an electronic form; however, the information has not yet been released. 
environmental improvement expenditure portion of the local education budget. The Busan Metropolitan Office of Education (2016) states that expenses for seismic retrofit of school buildings are funded by the environmental improvement expenditure from general subsidies, special subsidies in the case of disaster, and other subsidies. The Incheon Metropolitan Office of Education (2015) and the Gyeonggido Office of Education (2017) also claim that these are the sources of their budget. Even though the environmental improvement expenditure covers not only the budget for seismic evaluation and reinforcements but also for other expenses such as fixing light fixtures or renovations to reduce the level of asbestos, the ratio of the amount of the environmental improvement expenditure to the total local education budget shows the capacity each school district has for safety resource allocation.

The local education budget consists of a local education subsidy, fiscal transfers from corresponding provincial offices, and its own income (Board of Audit and Inspection, 2015). The major source of income for each school district is general subsidies under the Local Education Subsidy Act (Act No.14157, 29 May 2016), and the general subsidies, which comprise $96 \%$ of the total subsidies, are distributed according to the amount of deficiency, as per article 5.

Fiscal independence speaks to how much autonomy each school district has with respect to their fiscal policy. Although each school district has autonomy with respect to its budget, the amount distributed as subsidies for educational environment improvement expenses varies from year to year (Board of Audit and Inspection, 2015). Such uncertainties may affect how each education office reacts to the demands on safety measures or making decisions.

Individual local tax burden, which is the amount of local tax paid per residents, reveals the economic condition of each district and may also be proportional to demands for safety. The proportion of local tax contributed to the local education budget is only a fraction; however, residents may think that local taxes are used for education than other forms of taxation, since the local education tax is proportional to local tax, according to article 151 of Local Tax Act (Act No. 14033, 29 February 2016) and is part of the same tax bill.

Previous cross-country studies have utilized Polity IV data from Center for Systematic Peace to measure the level of democracy in different states (Escaleras et al., 2007; Lin, 2014); however, since such measures are not provided at subnational level, this study used election data provided by the National Election Commission instead to measure political participation and the kind of political environment elected officials face. Voter turnout rate, showing the political participation of the district, is the percentage of eligible voters who cast a ballot in an election. The election winning/lagging margin is the difference in the percentage of votes 
between the winner and the runner-up in each district, which is useful information because those elected do not always win in every district. It only contains positive values; therefore, the smaller value indicates how competitive the election was. In the UK, politically marginal areas are more likely to be characterized by a higher than expected number of hospitals (Bloom, Propper, Seiler, \& Van Reenen, 2015). The safety of school buildings is, like the provision of hospitals, a public service that elected officials will help to ensure according to the demand so as to maximize their vote. Whether those elected won in the district was also considered as a dummy variable.

The study also drew on a concordance of the political orientation of superintendents of each school district and their corresponding local governors. According to Jeong and Han (2015), the political orientation of the local governor and the superintendent affect the local expenditure for educational facilities. Jeong and Han (2015) also show that when the political orientation of the local governor and superintendent match, the expenditure for educational facilities increases and that the likelihood of collaboration between the two may affect how the local educational expenditure is distributed. Choi (2013) has shown that the amount of subsidies local governments supply to special accounts for educational expenses is affected by whether the local governor and superintendent have the same political orientation. The political orientations of superintendents are collected from previous studies where resources from media were utilized to identify the political orientation of each (Lee \& Chang, 2014; Kim \& Jang, 2015).

The level of integrity of each education office, which is announced by the Anticorruption and Civil Rights Commission annually, is broken down into external and internal integrity, which are measured from the perspectives of clients and public officials, respectively.

Lastly, physical properties of school buildings were used to measure the technical factors that may affect decisions pertaining to whether to carry out a seismic evaluation. Physical properties of each school building such as building age, gross floor area in square meters, number of floors, and what they are used for were considered. Whether a school is private or public has been controlled for, since private schools are more likely to be funded by the private foundations. Table 5 summarizes the variables. 
Table 5. Variables Used in This Study

\begin{tabular}{|c|c|c|}
\hline Variable & Description & Source \\
\hline Seismic Evaluation & $0:$ not yet undertaken; 1 : undertaken & Office of Education \\
\hline $\begin{array}{l}\text { Environmental } \\
\text { Improvement } \\
\text { Expenditure Ratio }\end{array}$ & $\begin{array}{l}\text { ratio of amount of environmental } \\
\text { improvement expenditure to total local } \\
\text { education budget }\end{array}$ & Office of Education \\
\hline $\begin{array}{l}\text { Local Education } \\
\text { Budget }\end{array}$ & based on settlement of account (in $\# 1$ billion) & Office of Education \\
\hline Fiscal Independence & $\begin{array}{l}\text { (subsidy for local education + transfer } \\
\text { from local government + direct-income) / } \\
\text { settlement x } 100\end{array}$ & $\begin{array}{l}\text { Local Education } \\
\text { Financial Information } \\
\text { Service }\end{array}$ \\
\hline $\begin{array}{l}\text { Individual Local Tax } \\
\text { Burden }\end{array}$ & $\begin{array}{l}\text { total local tax collected divided by the number } \\
\text { of residents (in } \# 1,000 \text { ) }\end{array}$ & $\begin{array}{l}\text { Local Education } \\
\text { Financial Information } \\
\text { Service }\end{array}$ \\
\hline Voter Turnout Rate & voter turnout rate in each district & $\begin{array}{l}\text { National Election } \\
\text { Commission }\end{array}$ \\
\hline $\begin{array}{l}\text { Winning/Lagging } \\
\text { Margin }\end{array}$ & $\begin{array}{l}\text { margin between the winner and the runner- } \\
\text { up in each district }\end{array}$ & $\begin{array}{l}\text { National Election } \\
\text { Commission }\end{array}$ \\
\hline Dissent & $\begin{array}{l}\text { 0: the elected official won in the district; } \\
\text { 1: the elected official lost in the district }\end{array}$ & $\begin{array}{l}\text { National Election } \\
\text { Commission }\end{array}$ \\
\hline Level of Integrity & based on the composite integrity index & $\begin{array}{l}\text { Anticorruption } \\
\text { and Civil Rights } \\
\text { Commission }\end{array}$ \\
\hline Concordance & $\begin{array}{l}\text { 0: local governor and superintendent have } \\
\text { different political orientations; } \\
\text { 1: local governor and superintendent have } \\
\text { the same political orientation }\end{array}$ & $\begin{array}{l}\text { National Election } \\
\text { Commission } \\
\text { Lee \& Chang, 2014; } \\
\text { Kim \& Jang, } 2015\end{array}$ \\
\hline Number of Floors & number of floors above ground & Office of Education \\
\hline Gross Floor Area & area in square meters & Office of Education \\
\hline Building Age & number of years since construction (in years) & Office of Education \\
\hline School Grade & 0: elementary; 1 : middle; 2 : high; 3 : special & Office of Education \\
\hline $\begin{array}{l}\text { Number of Students } \\
\text { and Faculty }\end{array}$ & $\begin{array}{l}\text { number of students and faculty in each } \\
\text { school combined each year }\end{array}$ & $\begin{array}{l}\text { School Information } \\
\text { Service }\end{array}$ \\
\hline Building Type & $\begin{array}{l}\text { 0: other; 1: auditorium; 2: classroom; } \\
\text { 3: cafeteria; 4: dormitory; 5: gym }\end{array}$ & Office of Education \\
\hline Private/Public & 0: private; 1 : public & Office of Education \\
\hline
\end{tabular}




\section{Model}

As the dependent variable is a binary categorical variable that specifies whether a school building has been seismically evaluated or not, a logistic regression method was employed. Since each education office makes the decisions regarding school buildings in its own jurisdiction, each office is fixed. Moreover, because each year when it is time to decide which buildings to evaluate, those that have not yet been evaluated are prioritized, the number of years since 2010 is also controlled. Although the structural type of school buildings was considered, since most buildings constructed in concrete are seismically evaluated as a matter of course, this variable is dropped in the analysis.

The basic model is specified as the following form:

$$
\log \left(\frac{p_{i j k t}}{1-p_{i j k t}}\right)=\mathrm{X}_{\mathrm{e}, j k t} \beta_{\mathrm{e}}+\mathrm{X}_{\mathrm{p}, j k t} \beta_{\mathrm{p}}+\mathrm{X}_{\mathrm{h}, i t} \beta_{\mathrm{h}}+\alpha_{k}+\delta_{t}
$$

where $p_{i j k t}$ is the probability that individual building $i$ in $j$ local government of provincial school district $k$ will be seismically evaluated in year $t . \mathrm{X}_{\mathrm{e}}$ is a matrix of economic factors that includes school district-level elements such as environment improvement expenditure ratio, local education budget, and fiscal independence, and a local government-level variable, the individual local tax burden. $\mathrm{X}_{\mathrm{p}}$ is a matrix of political factors that includes voter turnout rate, winning/lagging margin, whether the elected superintendent lost in the district, whether the local governor and superintendent have the same political orientation, and the level of integrity of school districts. $\mathrm{X}_{\mathrm{h}}$ is a matrix of technical factors including time-invariant variables such as the number of floors, gross floor area, school grade, and building type, as well as time-variant variables such as building age and number of students and faculty.

\section{RESULTS}

The number of school buildings analyzed in this study is 15,005. Table 6 shows that, on average, $1.73 \%$ of the total number of school buildings were seismically evaluated. Table 7 reports the average number of seismic evaluations by school district and year. Some districts evaluated more school buildings than others, and the number of evaluations performed each year also varied by school district.

Table 8 documents the correlation among the variables. Number of floors and gross floor area have high correlation, 0.744 ; however, both variables feature widely in determinations of which buildings should be seismically evaluated, and so both variables are used in this analysis. 
Table 6. Summary Statistics of Selected Variables

\begin{tabular}{l|c|c|c|l|l|l}
\hline & $\mathbf{n}$ & $\mathbf{T}$ & \multicolumn{1}{|c}{ Mean } & \multicolumn{1}{|c}{ SD } & \multicolumn{1}{|c}{ Min } & \multicolumn{1}{c}{ Max } \\
\hline Seismic Evaluation & 15005 & 5 & 0.0173 & 0.1305 & 0 & 1 \\
\hline Private/Public & 15005 & 5 & 0.8070 & 0.3946 & 0 & 1 \\
\hline $\begin{array}{l}\text { Environmental Improvement } \\
\text { Expenditure Ratio }\end{array}$ & 15005 & 5 & 2.7268 & 0.8410 & 0.8600 & 5.0622 \\
\hline $\begin{array}{l}\text { Local Education Budget } \\
\text { (in } 1 \text { billion) }\end{array}$ & 15005 & 5 & 5223.33 & 3507.297 & 1789.77 & 12486.6 \\
\hline Fiscal Independence & 15005 & 5 & 85.5505 & 3.6897 & 76.9 & 92 \\
\hline $\begin{array}{l}\text { Individual Local Tax Burden } \\
\text { (in 1,000) }\end{array}$ & 15005 & 5 & 415.721 & 187.0828 & 98 & 1226 \\
\hline Voter Turnout Rate & 15005 & 5 & 0.6133 & 0.0888 & 0.4546 & 0.8164 \\
\hline Winning/Lagging Margin & 15005 & 5 & 0.2008 & 0.1498 & 0.0010 & 0.6218 \\
\hline Dissent & 15005 & 5 & 0.1023 & 0.3031 & 0 & 1 \\
\hline Level of Integrity & 15005 & 5 & 7.2865 & 0.5274 & 5.57 & 8.35 \\
\hline Concordance & 15005 & 5 & 0.7008 & 0.4579 & 0 & 1 \\
\hline Number of Floors & 15005 & 5 & 2.7175 & 1.3002 & 1 & 12 \\
\hline Gross Floor Area (square meters) & 15005 & 5 & 2526.56 & 2508.42 & 17 & 29071 \\
\hline Building Age (Years) & 15004 & 5 & 23.5248 & 12.9133 & 0 & 90 \\
\hline Number of Students and Faculty & 15004 & 5 & 564.574 & 469.164 & 2 & 2691 \\
\hline
\end{tabular}

Table 7. Average Number of Seismic Evaluations by Year and District

\begin{tabular}{l|c|c|c|c|c|c}
\hline $\begin{array}{c}\text { Office of } \\
\text { Education }\end{array}$ & $\mathbf{N}$ & $\mathbf{2 0 1 1}$ & $\mathbf{2 0 1 2}$ & $\mathbf{2 0 1 3}$ & $\mathbf{2 0 1 4}$ & $\mathbf{2 0 1 5}$ \\
\hline Seoul & 2333 & 0.0051 & 0.0133 & 0.0159 & 0.0201 & 0.0261 \\
\hline Gyeonggi & 3055 & 0.0016 & 0.0029 & 0.0033 & 0.0036 & 0.0036 \\
\hline Gangwon & 1401 & 0.0121 & 0.0236 & 0.0393 & 0.0471 & 0.0514 \\
\hline Chungbuk & 924 & 0.0054 & 0.0108 & 0.0173 & 0.0260 & 0.0325 \\
\hline Chungnam & 1461 & 0.0034 & 0.0089 & 0.0116 & 0.0123 & 0.0554 \\
\hline Jeonbuk & 1715 & 0.0117 & 0.0157 & 0.0187 & 0.0192 & 0.0222 \\
\hline Jeonnam & 2219 & 0.0032 & 0.0032 & 0.0045 & 0.0045 & 0.0045 \\
\hline Gyeongbuk & 1862 & 0.0118 & 0.0297 & 0.0460 & 0.0596 & 0.0691 \\
\hline
\end{tabular}


Table 8. Correlation among Variables

\begin{tabular}{|c|c|c|c|c|c|c|c|c|c|c|}
\hline & (1) & (2) & (3) & (4) & (5) & (6) & (7) & (8) & (9) & (10) \\
\hline \multicolumn{11}{|l|}{$\begin{array}{l}\text { (1) Env } \\
\text { Improvement } \\
\text { Expenditure Ratio }\end{array}$} \\
\hline $\begin{array}{l}\text { (2) Local Education } \\
\text { Budget }\end{array}$ & -0.442 & & & & & & & & & \\
\hline $\begin{array}{l}\text { (3) Fiscal } \\
\text { Independence }\end{array}$ & -0.114 & 0.314 & & & & & & & & \\
\hline $\begin{array}{l}\text { (4) Individual Local } \\
\text { Tax Burden }\end{array}$ & -0.076 & 0.213 & -0.200 & & & & & & & \\
\hline $\begin{array}{l}\text { (5) Voter Turnout } \\
\text { Rate }\end{array}$ & 0.211 & -0.397 & -0.123 & -0.476 & & & & & & \\
\hline $\begin{array}{l}\text { (6) Winning/ Lagging } \\
\text { Margin }\end{array}$ & 0.170 & -0.349 & -0.037 & -0.018 & 0.157 & & & & & \\
\hline (7) Level of Integrity & 0.095 & -0.209 & -0.238 & 0.129 & -0.217 & 0.076 & & & & \\
\hline (8) Number of Floors & -0.200 & 0.308 & 0.256 & -0.047 & -0.237 & -0.15 & -0.134 & & & \\
\hline (9) Gross Floor Area & -0.163 & 0.308 & 0.189 & -0.014 & -0.219 & -0.100 & -0.090 & 0.744 & & \\
\hline (10) Building Age & -0.021 & -0.104 & -0.056 & -0.100 & 0.13 & 0.089 & -0.047 & 0.062 & 0.033 & \\
\hline $\begin{array}{l}\text { (11) Number of } \\
\text { Students and } \\
\text { Faculty }\end{array}$ & -0.212 & 0.388 & 0.298 & -0.039 & -0.321 & -0.160 & -0.130 & 0.492 & 0.416 & -0.112 \\
\hline
\end{tabular}

The results recording the effect of economic, political and technical factors on the likelihood of a seismic evaluation being undertaken are presented in table 9 . Model 1 shows that the ratio of the amount of the environmental improvement expenditure to the local educational budget is positively associated with the likelihood of a seismic evaluation being carried out. While the local educational budget is not significantly associated, the proportion of the budget financing seismic evaluation is. As the model proceeds to the full model, model 3, the association stays the same, suggesting that the effect of economic factors is positive and strong when it comes to the implementation of safety measures. Fiscal independence also has positive association with the likelihood of a seismic evaluation being undertaken. Individual local tax burden shows a similar association as the rest. Hence, the result is consistent with the first hypothesis. Regions that allocate more of their budget to environmental improvements in school buildings and that are fiscally independent of the central government are more likely to have safer school buildings. 
Table 9. The Effect of Economic, Political, and Technical Factors on the Likelihood of Seismic Evaluation Being Undertaken

\begin{tabular}{|c|c|c|c|}
\hline & (1) & (2) & (3) \\
\hline $\begin{array}{l}\text { Environmental Improvement } \\
\text { Expenditure Ratio }\end{array}$ & $\begin{array}{l}0.6991^{\star \star \star} \\
(0.133)\end{array}$ & $\begin{array}{l}0.6198^{\star \star \star} \\
(0.126)\end{array}$ & $\begin{array}{c}0.9440^{\star \star \star} \\
(0.171)\end{array}$ \\
\hline Local Education Budget & $\begin{array}{l}0.0006 \\
(0.001)\end{array}$ & $\begin{array}{l}0.0003 \\
(0.000)\end{array}$ & $\begin{array}{r}-0.0001 \\
(0.001)\end{array}$ \\
\hline Fiscal Independence & $\begin{array}{l}0.1095^{\star \star \star} \\
(0.042)\end{array}$ & $\begin{array}{l}0.1184^{\star \star \star} \\
(0.044)\end{array}$ & $\begin{array}{l}0.1706^{\star * \star} \\
(0.063)\end{array}$ \\
\hline Individual Local Tax Burden & $\begin{array}{c}0.0024^{* * *} \\
(0.001)\end{array}$ & $\begin{array}{c}0.0015^{\star *} \\
(0.001)\end{array}$ & $\begin{array}{l}0.0028^{\star *} \\
(0.001)\end{array}$ \\
\hline Voter Turnout Rate & & $\begin{array}{c}-4.3943^{\star * *} \\
(1.307)\end{array}$ & $\begin{array}{l}1.0418 \\
(2.448)\end{array}$ \\
\hline Winning/Lagging Margin & & $\begin{array}{l}-1.7414^{\star \star} \\
(0.792)\end{array}$ & $\begin{array}{l}-3.3458^{\star \star \star} \\
(1.208)\end{array}$ \\
\hline Dissent & & $\begin{array}{l}-0.3409 \\
(0.306)\end{array}$ & $\begin{array}{l}-0.3019 \\
(0.549)\end{array}$ \\
\hline Level of Integrity & & $\begin{array}{c}-0.7393^{\star \star \star} \\
(0.175)\end{array}$ & $\begin{array}{c}-0.9071^{\star \star \star} \\
(0.238)\end{array}$ \\
\hline Concordance & & $\begin{array}{l}1.3081^{\star \star \star} \\
(0.442)\end{array}$ & $\begin{array}{l}1.3721^{\star *} \\
(0.663)\end{array}$ \\
\hline Number of Floors & & & $\begin{array}{l}3.3535^{\star * \star} \\
(0.298)\end{array}$ \\
\hline Gross Floor Area & & & $\begin{array}{l}0.0006^{\star * \star} \\
(0.000)\end{array}$ \\
\hline Building Age & & & $\begin{array}{l}-0.0417^{* *} \\
(0.019)\end{array}$ \\
\hline 1. Auditorium & & & $\begin{array}{l}-2.7484 \\
(1.974)\end{array}$ \\
\hline 2. Classroom & & & $\begin{array}{l}2.6431^{*} \\
(1.551)\end{array}$ \\
\hline 3. Cafeteria & & & $\begin{array}{l}-0.9844 \\
(2.182)\end{array}$ \\
\hline 4. Dormitory & & & $\begin{array}{l}-0.4480 \\
(2.031)\end{array}$ \\
\hline 1. Middle School & & & $\begin{array}{c}-0.2538 \\
(0.492) \\
\end{array}$ \\
\hline 2. High School & & & $\begin{array}{c}-4.8125^{\star \star \star} \\
(0.612) \\
\end{array}$ \\
\hline 3. Special School & & & $\begin{array}{l}-4.5080 \\
(3.031)\end{array}$ \\
\hline Number of Students and Faculty & & & $\begin{array}{c}0.0025^{\star * \star} \\
(0.001)\end{array}$ \\
\hline Private/Public & $\begin{array}{c}7.9014^{\star \star \star} \\
(0.506)\end{array}$ & $\begin{array}{c}7.0854^{\star * *} \\
(0.422)\end{array}$ & $\begin{array}{c}7.8291^{* * *} \\
(0.993)\end{array}$ \\
\hline Constant & $\begin{array}{c}-498.1728^{* \star \star} \\
(5.268)\end{array}$ & $\begin{array}{l}-34.2103^{* * *} \\
(5.743)\end{array}$ & $\begin{array}{l}-74.6432^{\star \star \star} \\
(8.420)\end{array}$ \\
\hline Observations & 74,969 & 74,969 & 74,086 \\
\hline Number of Buildings & 15,005 & 15,005 & 14,973 \\
\hline Log-Likelihood & -2616 & -2547 & -2219 \\
\hline Wald Chi-Square & $1492.77^{\star \star \star}$ & $1427.20^{\star \star \star}$ & $2046.54^{\star \star \star}$ \\
\hline
\end{tabular}

Notes: Standard errors are in parentheses. All regressions include regional fixed effects and control for structural type and year. Concordance is a dummy variable on whether the local governor and the superintendent have same political orientation; 1 means that they have same political orientation. Private/public and Dissent are dummy variables with 1 being public and the elected lost in the district, respectively.

${ }^{* * *} p<.01 ;{ }^{* *} p<.05 ;{ }^{*} p<.1$. 
Model 2 shows that voter turnout rate is negatively associated with the likelihood of a seismic evaluation being carried out; however, this association disappears when technical factors are considered. When technical factors, the criteria on which the preliminary evaluation process is based, are factored into the equation, political participation, represented by turnout rate, is not significantly associated. On the other hands, the association with the winning/lagging margin, which measures how competitive a given election was, stays significant throughout the model, indicating that schools in districts that had experienced competitive election were more likely to be seismically evaluated. The effects of political participation in this case bear out the literature on democracy and human vulnerability; however, the meaning behind these results needs to be carefully examined. Whether the winner won in the given voting district is not significantly associated, and when the local governor and the superintendent have same political orientation, schools in the district are more likely to be seismically evaluated. Therefore, the second hypothesis is partly supported. The level of integrity is negatively associated, showing that corruption is positively associated with the likelihood of a seismic evaluation being undertaken. This result is not consistent with the third hypothesis.

The results of the effects of technical factors bear out the significance of the criteria many education offices utilize. More floors, higher gross floor area, and higher numbers of students and faculty increase the likelihood that a seismic evaluation will be undertaken. Classroom buildings are more likely to be evaluated before other types of buildings, since as most plans indicate, they are the area students and faculty spend the most time in. High school buildings are less likely to be evaluated before elementary school buildings, as the plans specify. Building age is negatively associated; this result, however, was anticipated because the plans try to prioritize evaluation of buildings that are likely to be used for longer periods of time, thus making reinforcement cost effectives. Hence, the results are consistent with the fifth hypothesis. 
Table 10. The Effect of Political Factors on Budget Spending and the Likelihood of Seismic Evaluation Being Undertaken

\begin{tabular}{|c|c|c|c|c|c|}
\hline & (1) & (2) & (3) & (4) & (5) \\
\hline $\begin{array}{l}\text { Env Improvement } \\
\text { Expenditure Ratio }\end{array}$ & $\begin{array}{l}1.3178 \\
(0.979)\end{array}$ & $\begin{array}{c}1.4383^{\star * *} \\
(0.244)\end{array}$ & $\begin{array}{l}0.4418^{* *} \\
(0.192)\end{array}$ & $\begin{array}{l}-1.6949 \\
(3.305)\end{array}$ & $\begin{array}{l}0.1221 \\
(0.661)\end{array}$ \\
\hline $\begin{array}{l}\text { Individual Local Tax } \\
\text { Burden }\end{array}$ & $\begin{array}{c}0.0026^{* *} \\
(0.001)\end{array}$ & $\begin{array}{l}0.0026^{*} \\
(0.001)\end{array}$ & $\begin{array}{c}0.0039^{\star * \star} \\
(0.001)\end{array}$ & $\begin{array}{l}0.0025^{\star} \\
(0.001)\end{array}$ & $\begin{array}{c}0.0028^{* \star} \\
(0.001)\end{array}$ \\
\hline Fiscal Independence & $\begin{array}{l}0.1573^{\star *} \\
(0.061)\end{array}$ & $\begin{array}{c}0.2043^{\star \star \star} \\
(0.064)\end{array}$ & $\begin{array}{c}0.2171^{\star \star \star} \\
(0.062)\end{array}$ & $\begin{array}{l}0.1532^{\star *} \\
(0.065)\end{array}$ & $\begin{array}{c}0.1650^{\star \star \star} \\
(0.061)\end{array}$ \\
\hline $\begin{array}{l}\text { Env Improvement } \\
\text { Expenditure Ratio } \\
\text { x Voter Turnout Rate }\end{array}$ & $\begin{array}{l}-0.6778 \\
(1.597)\end{array}$ & & & & \\
\hline $\begin{array}{l}\text { Env Improvement } \\
\text { Expenditure Ratio } \\
\text { x Wining/Lagging } \\
\text { Margin }\end{array}$ & & $\begin{array}{c}-3.2751^{* * *} \\
(1.138)\end{array}$ & & & \\
\hline $\begin{array}{l}\text { Env Improvement } \\
\text { Expenditure Ratio } \\
\text { x Dissent }\end{array}$ & & & $\begin{array}{l}1.7755^{\star \star \star} \\
(0.310)\end{array}$ & & \\
\hline $\begin{array}{l}\text { Env Improvement } \\
\text { Expenditure Ratio } \\
\text { x Level of Integrity }\end{array}$ & & & & $\begin{array}{l}0.3496 \\
(0.434)\end{array}$ & \\
\hline $\begin{array}{l}\text { Env Improvement } \\
\text { Expenditure Ratio } \\
\text { x Concordance }\end{array}$ & & & & & $\begin{array}{l}0.8329 \\
(0.670)\end{array}$ \\
\hline Voter Turnout Rate & $\begin{array}{l}3.1197 \\
(4.835)\end{array}$ & $\begin{array}{l}1.0262 \\
(2.491)\end{array}$ & $\begin{array}{l}1.8715 \\
(2.418)\end{array}$ & $\begin{array}{l}0.7814 \\
(2.608)\end{array}$ & $\begin{array}{l}1.1651 \\
(2.410)\end{array}$ \\
\hline Winning/Lagging Margin & $\begin{array}{c}-3.3573^{\star \star \star} \\
(1.177)\end{array}$ & $\begin{array}{l}6.0206^{\star} \\
(3.483)\end{array}$ & $\begin{array}{c}-3.5915^{\star \star \star} \\
(1.239)\end{array}$ & $\begin{array}{c}-3.3216^{\star \star \star} \\
(1.251)\end{array}$ & $\begin{array}{c}-3.1497^{\star \star \star} \\
(1.179)\end{array}$ \\
\hline Dissent & $\begin{array}{l}-0.2018 \\
(0.540)\end{array}$ & $\begin{array}{c}-0.0710 \\
(0.550)\end{array}$ & $\begin{array}{c}-5.3613^{\star \star \star} \\
(1.041)\end{array}$ & $\begin{array}{c}-0.2562 \\
(0.563)\end{array}$ & $\begin{array}{l}-0.3145 \\
(0.539)\end{array}$ \\
\hline Level of Integrity & $\begin{array}{c}-0.8762^{\star \star \star} \\
(0.232)\end{array}$ & $\begin{array}{l}-0.7761^{* * *} \\
(0.239)\end{array}$ & $\begin{array}{c}-0.7919^{\star \star \star} \\
(0.242)\end{array}$ & $\begin{array}{l}-2.1148 \\
(1.508)\end{array}$ & $\begin{array}{c}-0.8336^{\star \star \star} \\
(0.235)\end{array}$ \\
\hline Concordance & $\begin{array}{l}1.2691^{* \star} \\
(0.641)\end{array}$ & $\begin{array}{c}1.4245^{\star *} \\
(0.664)\end{array}$ & $\begin{array}{c}1.6135^{\star *} \\
(0.674)\end{array}$ & $\begin{array}{l}1.5124^{\star *} \\
(0.718)\end{array}$ & $\begin{array}{r}-0.7171 \\
(1.719)\end{array}$ \\
\hline Constant & $\begin{array}{c}-72.557^{\star \star \star} \\
(8.566)\end{array}$ & $\begin{array}{c}-79.239^{\star \star \star} \\
(8.599)\end{array}$ & $\begin{array}{c}-78.227^{\star \star \star} \\
(8.347)\end{array}$ & $\begin{array}{c}-65.978^{\star \star \star} \\
(15.160)\end{array}$ & $\begin{array}{c}-72.028^{\star \star \star} \\
(8.261)\end{array}$ \\
\hline Observations & 74,086 & 74,086 & 74,086 & 74,086 & 74,086 \\
\hline Number of Buildings & 14,973 & 14,973 & 14,973 & 14,973 & 14,973 \\
\hline Log-Likelihood & -2227 & -2217 & -2202 & -2215 & -2223 \\
\hline LR-Test & -15.56 & $4.48^{\star \star}$ & $33.50^{\star \star \star}$ & $9.10^{\star \star \star}$ & -8.51 \\
\hline
\end{tabular}

Notes: Standard errors are in parentheses. All regressions include regional fixed effects and control for structural type, whether the school is private or public, and technical factors. Concordance is a dummy variable on whether the local governor and the superintendent have same political orientation; 1 means that they have same political orientation. Private/public and Dissent are dummy variables with 1 being public and the elected lost in the district, respectively. The likelihood ratio test tests whether the interactive model improves on the noninteractive model.

*** $p<.01 ;{ }^{* *} p<.05 ;{ }^{*} p<.1$. 
Table 11. The Effect of Technical Factors on Budget Spending and the Likelihood of Seismic Evaluation Being Undertaken

\begin{tabular}{|c|c|c|c|c|}
\hline & (1) & (2) & (3) & (4) \\
\hline $\begin{array}{l}\text { Env Improvement } \\
\text { Expenditure Ratio }\end{array}$ & $\begin{array}{l}1.0497^{\star *} \\
(0.512)\end{array}$ & $\begin{array}{l}0.9370^{\star * \star} \\
(0.279)\end{array}$ & $\begin{array}{l}-0.3264 \\
(0.409)\end{array}$ & $\begin{array}{l}1.2449^{* \star *} \\
(0.266)\end{array}$ \\
\hline Local Education Budget & $\begin{array}{l}-0.0000 \\
(0.001)\end{array}$ & $\begin{array}{l}-0.002 \\
(0.001)\end{array}$ & $\begin{array}{l}0.0000 \\
(0.001)\end{array}$ & $\begin{array}{l}-0.0001 \\
(0.001)\end{array}$ \\
\hline Fiscal Independence & $\begin{array}{l}0.1581^{\star *} \\
(0.063)\end{array}$ & $\begin{array}{l}0.1745^{\star *} \\
(0.068)\end{array}$ & $\begin{array}{l}0.0026^{*} \\
(0.063)\end{array}$ & $\begin{array}{l}0.0029^{* *} \\
(0.064)\end{array}$ \\
\hline Concordance & $\begin{array}{l}1.3042^{*} \\
(0.666)\end{array}$ & $\begin{array}{l}1.4054^{* *} \\
(0.711)\end{array}$ & $\begin{array}{l}1.4226^{\star *} \\
(0.674)\end{array}$ & $\begin{array}{l}1.3699^{* *} \\
(0.673)\end{array}$ \\
\hline $\begin{array}{l}\text { Env Improvement } \\
\text { Expenditure Ratio } \\
\text { x Number of Floors }\end{array}$ & $\begin{array}{l}-0.0320 \\
(0.148)\end{array}$ & & & \\
\hline $\begin{array}{l}\text { Env Improvement } \\
\text { Expenditure Ratio } \\
\text { x Gross Floor Area }\end{array}$ & & $\begin{array}{l}0.0000 \\
(0.000)\end{array}$ & & \\
\hline $\begin{array}{l}\text { Env Improvement } \\
\text { Expenditure Ratio } \\
\text { x Building Age }\end{array}$ & & & $\begin{array}{c}0.0484^{\star \star *} \\
(0.014)\end{array}$ & \\
\hline $\begin{array}{l}\text { Env Improvement } \\
\text { Expenditure Ratio } \\
\text { x Number of Students } \\
\text { and Faculty }\end{array}$ & & & & $\begin{array}{l}-0.0005 \\
(0.000)\end{array}$ \\
\hline Number of Floors & $\begin{array}{c}3.6366^{\star \star \star} \\
(0.000)\end{array}$ & $\begin{array}{c}3.5798^{\star \star \star} \\
(0.000)\end{array}$ & $\begin{array}{c}0.0006^{\star \star \star} \\
(0.000)\end{array}$ & $\begin{array}{c}0.0006^{\star \star \star} \\
(0.000)\end{array}$ \\
\hline Gross Floor Area & $\begin{array}{l}0.0006^{\star \star \star} \\
(0.000)\end{array}$ & $\begin{array}{l}0.0007^{\star \star \star} \\
(0.000)\end{array}$ & $\begin{array}{l}0.0006^{\star \star \star} \\
(0.000)\end{array}$ & $\begin{array}{l}0.0006^{\star \star \star} \\
(0.000)\end{array}$ \\
\hline Building Age & $\begin{array}{l}-0.0239 \\
(0.019)\end{array}$ & $\begin{array}{l}-0.0488^{* *} \\
(0.020)\end{array}$ & $\begin{array}{l}-0.1468^{* * *} \\
(0.042)\end{array}$ & $\begin{array}{l}-0.0390^{* *} \\
(0.019)\end{array}$ \\
\hline $\begin{array}{l}\text { Number of Students and } \\
\text { Faculty }\end{array}$ & $\begin{array}{l}0.0023^{* * *} \\
(0.001)\end{array}$ & $\begin{array}{l}0.0024^{* * *} \\
(0.001)\end{array}$ & $\begin{array}{c}0.0023^{* * *} \\
(0.001)\end{array}$ & $\begin{array}{c}0.0039^{* * \star} \\
(0.001)\end{array}$ \\
\hline Constant & $\begin{array}{l}-75.1307^{* * \star} \\
(8.616)\end{array}$ & $\begin{array}{l}-78.3137^{* \star *} \\
(9.058)\end{array}$ & $\begin{array}{l}-73.2755^{\star \star \star} \\
(8.621)\end{array}$ & $\begin{array}{c}-76.9854^{* * *} \\
(8.601)\end{array}$ \\
\hline Observations & 74,086 & 74,086 & 74,086 & 74,086 \\
\hline Number of Buildings & 14,973 & 14,973 & 14,973 & 14,973 \\
\hline Log Likelihood & -2218 & -2211 & -2213 & -2213 \\
\hline Likelihood Ratio Test & 1.54 & $16.16^{\star \star \star}$ & $11.49^{\star \star \star}$ & $12.71^{\star \star *}$ \\
\hline
\end{tabular}

Notes: Standard errors are in parentheses. All regressions include regional fixed effects and control for year, structural type, building type, school grade, whether the school is private or public, and political factors. Concordance is a dummy variable on whether the local governor and the superintendent have same political orientation; 1 means that they have same political orientation. Private/public and Dissent are dummy variables with 1 being public and the elected lost in the district, respectively. The likelihood Ratio Test tests whether the interactive model improves on the noninteractive model.

${ }^{* * *} p<.01 ;{ }^{* *} p<.05 ;{ }^{*} p<.1$. 
Tables 10 and 11 cover the effects of political and technical factors on economic factors and the likelihood of a seismic evaluation being carried out. If economic capacity constrains the quantity of safety measures that can be implemented in a region, political and technical factors may moderate those effects. The results show that the competitiveness of elections and whether the elected official lost in the district also moderate those effects. The more competitive an election, the higher the ratio of the amount of the environmental improvements expenditure to the total education budget, which increases the likelihood aseismic evaluation will be undertaken. Moreover, in districts where the elected official lost, the effect of economic capacity on the likelihood of an evaluation being undertaken also increases. Thus, the fourth hypothesis is partly supported.

Table 11 shows that among the technical factors, building age moderates the association between economic capacity and the likelihood of an evaluation being carried out. For school buildings older than 6.75 years, the ratio of the amount of the environmental improvement expenditure to total education budget is positively associated with the likelihood of a seismic evaluation being carried out, while for newer buildings this relationship is reversed. The results are weakly consistent with the sixth hypothesis.

\section{DISCUSSION}

Economic capacity is negatively associated with human vulnerability within a state, as the results pertaining the likelihood of the seismic evaluation of school buildings being undertaken indicate. Even when the properties of existing physical structures are considered, economic capacity still has an effect on the distribution of mitigation measures. Moreover, political and technical factors moderate the association between them.

The larger the amount of the budget allocated for safety and the greater the fiscal independence of a district, the greater the likelihood that safety measures will be implemented. Since seismic reinforcement is costly and school districts are always subject to budget constraints, the decision to whether to carry out an evaluation or not is likely to be affected by the amount of subsidies available. Financially dependent school districts may focus on the necessities first and rely on subsidies to cover the seismic reinforcement process. According to the Bureau of Audit and Inspection (2015), all education offices as well as the Ministry of Education prioritize the welfare budget over the environmental improvement budget and ignore demands for improvement of school facilities. Each education office autonomously allocates its 
budget using general subsidies as resources, prioritizing personnel, welfare, and operating expenses and allocating what remains of the budget to environment improvement (Bureau of Audit and Inspection, 2015). Individual local tax burden may play a dual role, indicating the economic capacity of a region as well as the demand for public services. Districts where individuals pay a higher local tax may also make more demands for public service, including the implementation of safety measures. Overall, even when economic capacity is detached from the physical properties of existing structures, school buildings in regions that allocate a higher proportion of their budgets to the environmental improvements and that have greater fiscal independence are less likely to be vulnerable.

The current direct election of superintendents in Korea was adopted under the principles of decentralization and residential control (Kwon, 2011; Kim \& Kim, 2015). Since education policy in the direct election system attends to the demands of the local population, the association between the competitiveness of elections and the likelihood of a seismic evaluation being undertaken could indicate that the current election system is responsive to these demands. Moreover, such responsiveness may not illustrate that an elected superintendent is rewarding the electorate for his or her victory in the district, because whether the superintendent loses does not have significant association. However, in districts where the elected superintendent lost, the effect of economic capacity on the likelihood of a seismic evaluation being carried out increases. Whether such an interpretation of the model reflects the actual process calls for further investigation.

Safety and environment improvement expenditures may be affected by the relationship between the local governor and the corresponding superintendent of education, as previous studies on the effect of conflict and collaboration between the two on educational expenses and subsidies show (Choi, 2013; Jeong \& Han, 2015). The conflict between local governors and superintendents over the free meal service also showed the importance of their collaboration (Kim \& Jang, 2015). The two may collaborate to gain leverage against the central government on budgeting or cooperate to secure enough funding to reinforce school buildings. The Seoul Metropolitan government provided additional funds to evaluate school buildings that also serve as emergency shelters (Seoul Metropolitan Office of Education, 2015b), which suggests that the local governor and the superintendent can collaborate for the safety of the region. Moreover, the collaboration between the two also implies that residents have more channels through which to express their demands.

Voter turnout rate, another variable that represents the level of political participation in a democratic state, was not significantly associated with the likelihood of a seismic evaluation being carried out once technical factors are introduced, which 
may indicate that the effect of political factors on human vulnerability across states is moderated by the condition of existing structures. However, this result could also be due to the nature of the variable, since the election for the superintendent of education is part of general local elections; the number of voters is aggregated, and so it is not possible to isolate the number of voters interested in educational matters.

The level of integrity was negatively associated with the likelihood of a seismic evaluation being undertaken, in contrast to findings by Escaleras, Anbarci, and Register (2007) and Kahn's intuition (2005). The discrepancy could be due to the nature of the index, as the level of integrity has external and internal aspects and also includes evaluations by the residents. Moreover, corruption may have a greater impact during post-disaster relief rather than pre-disaster preparation.

Overall, political factors, especially with respect to voting and political participation, still have a limited effect on the likelihood of a seismic evaluation being undertaken within a state. The political activities of voters in states with similar political institutions may not be the only factor in determining the level of natural disaster preparation and human vulnerability to such disasters. Rather, power politics may also play a role, as the likelihood of collaboration between the superintendent and corresponding local governor and the likelihood of a seismic evaluation being undertaken are strongly associated.

Within a democratic state, a set of process and procedures (the master plan in this case) governs the basic establishment and implementation of safety measures, which is shown by fact that the technical factors considered by the school districts are associated with the likelihood of a seismic evaluation being undertaken, as expected.

\section{CONCLUSION}

The varying death tolls across states and the influence of economic development and political factors show that human vulnerability to natural disasters can be improved by collective societal action. Protection provided by economic development and institutions is mediated by the implementation of disaster mitigation measures; seismic evaluation and reinforcement, being disaster mitigation measures, are expected to reduce casualties when the unpredictable disaster finally hits.

The results imply that the factors considered in cross-country studies still hold at national level; economic shortfall, irresponsible regimes, and unreliable institutions may exacerbate vulnerability. Further study is required to see if the preparations for other types of natural disasters differ from that for earthquakes; as Lin (2014) shows democracy is more effective in preventing casualties caused by predictable disasters 
rather than unpredictable disasters.

Given that "individuals face collective action problems, myopic behavior and asymmetric information" (Neumayer et al., 2014, p. 17), successful disaster mitigation measures could be developed through a master plan. School districts already make their decisions based on certain criteria that they use not only to make more efficient and rational decisions but also to promote transparency and fairness in the decision-making process. More comprehensive analyses need to be carried out, but the results show that even when the criteria are considered, economic and political factors are still associated with the likelihood of certain school buildings being prioritized for seismic evaluation and reinforcement. A comprehensive set of criteria based solely on the structural aspects of school buildings inevitably has limits, which could be addressed by the disclosure of information on how decisions are made and by providing opportunities for questioning those decisions.

Instead of blaming nature or poor management, society as a whole needs to prepare for the unpredictable. After all, the fundamental role of society is to provide a shield for the safety of all.

\section{Limitations}

First, the analytical model was set based on cross-country studies; however, it may not have fully incorporated local-level elements. Political institution factors from cross-country studies are considered, but the measurements, such as the winning/lagging margin, may not be a reliable representation of the level of democracy measured in cross-country studies. Such discrepancy may lead to inaccurate and erroneous interpretations.

Second, the mechanism by which decisions to carry out seismic evaluations needs closer examination. This study assumed that institutions use the mechanisms mentioned in several government documents, accessible via open.go.kr. Additional interviews with public officials in charge of making such decisions or representatives in local education councils may contribute to understanding the underlying mechanisms, which may shed light on the distribution of disaster mitigation measures. Moreover, not all education offices disclosed the criteria they use in making decisions as to whether to undertake seismic reinforcements. Major factors that they utilize have been considered, but these may not be sufficient to paint the whole picture. Also, some education offices may use different weights for each factor, but in this analysis, it is assumed that every factor has the same weight.

Furthermore, the fact that a seismic evaluation has been carried out could be an indicator that the school building is under renovation or construction. As stated in 
the master plan, seismic reinforcement on school buildings that are already under renovation is favored on the grounds of efficiency. Earthquakes had received much attention in Korea until the recent Gyungju and Pohang earthquakes. Students and parents may have more safety concerns about their school buildings with respect to earthquakes than the general population. Whether the likelihood of a seismic evaluation being undertaken is due to the demand for seismic mitigation measures or to the demand for 1 environmental improvements more generally needs to be addressed.

\section{REFERENCES}

Aldrich, D. P. 2012. Building resilience: Social capital in post-disaster recovery. Chicago: University of Chicago Press.

Anbarci, N., Escaleras, M., \& Register, C. A. 2005. Earthquake fatalities: The interaction of nature and political economy. Journal of Public Economics, 89(9-10): 1907-1933.

Bellet, D. 2004. Fundamental concepts and principles for assuring acceptable performance of schools and the education system. In School safety and security: Keeping schools safe in earthquakes. Retrieved from www.oecd-ilibrary.org/ education/keepi ng-schools-safe-in-earthquakes_9789264016705-en.

Bloom, N., Propper, C., Seiler, S., \& Van Reenen, J. 2015. The impact of competition on management quality: Evidence from public hospitals. Review of Economic Studies, 82(2): 457-489.

Brooks, N., Adger, W. N., \& Kelly, P. M. 2005. The determinants of vulnerability and adaptive capacity at the national level and the implications for adaptation. Global Environmental Change, part A, 15(2): 151-163.

Bueno de Mesquita, B., Smith, A., Siverson, R., \& Morrow, J. 2003. The logic of political survival. Cambridge, MA: MIT Press.

Busan Metropolitan Office of Education. 2016. School building seismic reinforcement plan (교육시설과-10767). Retrieved from www.open.go.kr/pa/infoWonmun/cateSearch/orginlDetail.do?prdnDt=20161212093100\&prdnNstRgst$\mathrm{No}=\mathrm{C} 10 \mathrm{CB} 163416938108000 \&$ returnUrl=/search/integrate/search.do\#hnp= 0.6743985440934115

Choi, Y. 2013. Analysis of the critical issues on superintendent's election system and political propensity coincidence between local governor and superintendent. Korean Comparative Government Review, 17(2): 243-261.

Chungcheongnamdo Office of Education. 2017. Changes in school building seismic 
reinforcement plan [2017-2020] (안전총괄과-837). Retrieved from www.open. go.kr/pa/infoWonmun/cateSearch/orginlDetail.do?prdnDt=20170209085300\&prdnNstRgstNo=N10CB170404744421000\&returnUrl=/search/integrate/search . do\#hnp=0.3757298941960854.

Cingranelli, D. L. 1981. Race, politics, and elites: Testing alternative models of municipal service distribution. American Journal of Political Science, 25(4): 664-692.

Cole, S., Healy, A., \& Werker, E. 2012. Do voters demand responsive governments? Evidence from Indian disaster relief. Journal of Development Economics, 97(2): 167-181.

Deaton, A. 2003. Health, inequality, and economic development. Journal of Economic Literature, 41(1): 113-58.

Delavallade, C. 2006. Corruption and distribution of public spending in developing countries. Journal of Economics and Finance, 30(2): 222-239.

Escaleras, M., Anbarci, N., \& Register, C. A. 2007. Public sector corruption and major earthquakes: A potentially deadly interaction. Public Choice, 132(1): 209-230.

Escaleras, M., \& Register, C. A. 2012. Fiscal decentralization and natural hazard risks. Public Choice, 151(1): 165-183.

Garrett, T. A., \& Sobel, R. S. 2003. The political economy of FEMA disaster payments. Economic Inquiry, 41(3): 496-509.

Gasper, J. T., \& Reeves, A. 2011. Make it rain? Retrospection and the attentive electorate in the context of natural disasters. American Journal of Political Science, 55(2): 340-355.

Griffin, J. D., \& Newman, B. 2005. Are voters better represented? Journal of Politics, 67(4): 1206-1227.

Gyeonggi Goyang Office of Education. 2016. School building seismic reinforcement plan (교육시설과-275). Retrieved from www.open.go.kr/pa/infoWonmun/cateSearch/orginlDetail.do?prdnDt $=20160119143400 \& p r d n N s t R g s t N o=J 10 C$ B160154440331000\&returnUrl=/search/integrate/search.do\#hnp=0.158349835 80785056.

Gyeonggi Yongin Office of Education. 2016. School building seismic reinforcement plan (교육 시설과-263). Retrieved from www.open.go.kr/pa/infoWonmun/cateSearch/orginlDetail.do?prdnDt=20160114152000\&prdnNstRgstNo=J10CB160144029702000\&retur$\mathrm{nUrl}=/$ search/integrate/search.do\#hnp=0.6526525248164032.

Gyeonggido Office of Education. 2015. Changes in school building seismic reinforcement plan (안전관리과-5515). Retrieved from www.open.go.kr/pa/infoWonmun/ cateSearch/orginlDetail.do?prdnDt=20151120094200\&prdnNstRgstNo=J10CB153239150026000\&returnUrl=/search/integrate/search.do\#hnp $=0.2014931$ 1335437536. 
Gyeonggido Office of Education. 2017. Plan for seismic reinforcement of school buildings to create earthquake-safe schools (안전관리과-400). Retrieved from www.open.go.kr/pa/infoWonmun/cateSearch/orginlDetail.do?prd$\mathrm{nDt}=20170117133000 \&$ prdnNstRgstNo $=\mathrm{J} 10 \mathrm{CB} 170174895224000 \&$ retur$\mathrm{nUrl}=/$ search/integrate/search.do\#hnp $=0.008999839252612718$.

Gyeongsangnamdo Office of Education. 2016. Budget for school building seismic reinforcement plan (시설과-7763). Retrieved from www.open.go.kr/pa/ infoWonmun/cateSearch/orginlDetail.do?prdnDt=20161004113300\&prdnNstRgstNo $=\mathrm{S} 10 \mathrm{CB} 162785497818000 \&$ returnUrl=/search/integrate/search . do\#hnp $=0.8416732590226619$.

Healy, A., \& Malhotra, N. 2009. Myopic voters and natural disaster policy. American Political Science Review, 103(3): 387-406.

Incheon Metropolitan Office of Education. 2015. School building seismic reinforcement plan (교육시설과-8157). Retrieved from www.open.go.kr/pa/infoWonmun/cateSearch/orginlDetail.do?prdnDt=20151116113800\&prdnNstRgst$\mathrm{No}=\mathrm{E} 10 \mathrm{CB} 153206619428000 \& \mathrm{returnUrl}=/ \mathrm{search} / \mathrm{integrate} / \mathrm{search}$. do\#hnp $=0.9910145642948256$.

Jeong, H., \& Han, Y. K. 2015. An analysis of determinant factors in local educational expenditure. Journal of Economics and Finance of Education, 24(4): 53-72.

Jha, A. K., Barenstein, J. D., Phelps, P. M., Pittet, D., \& Sena, S. 2010. Safer homes, stronger communities: A handbook for reconstructing after natural disasters. Washington, DC: World Bank.

Jones, E. C., \& Murphy, A. D. (eds.) 2009. The political economy of hazards and disasters. Lanham, MD: AltaMira Press.

Jung, S. C. 2012. A case study on the implementation of earthquake hazard mitigation policies: The case of the program for seismic retrofit of school buildings in the Seoul Metropolitan Office of Education. Seoul Studies, 13(3): 175-193.

Jung, S. C. 2013. An analysis on the formation and implementation process of the earthquake hazard mitigation policies: The case of the program for seismic retrofit of school buildings in the Seoul Metropolitan Office of Education. $\mathrm{PhD}$ diss. Retrieved from www.riss.kr/link?id=T13234943.

Kahn, M. E. 2005. The death toll from natural disasters: The role of income, geography, and institutions. Review of Economics and Statistics, 87(2): 271-284.

Keefer, P., Neumayer, E., \& Plümper, T. 2011. Earthquake propensity and the politics of mortality prevention. World Development, 39(9): 1530-1541.

Kim, M., \& Jang, J. 2015. Configurations of conditions affecting major educational policy projects of regional educational authorities: Application of QCA. Korean Journal of Local Government and Administration Studies, 29(4): 443-462. 
Korean Institute of Educational Environment. 2010. Directions in seismic reinforcement project [PowerPoint slides]. Retrieved from www.kisee.re.kr/rain/bbs/ board.php?bo_table=bbs_02_05_02\&wr_id=15.

Kwon, H. W. 2011. Issues and revising the direct election system for superintendent. Journal of Politics of Education, 18(2), 33-56.

Lee, D. 2015. Government administrative control tower in crisis management system: Definition, issues, and policy implications. Korean Journal of Policy Studies, 30(3): 125-145.

Lee, S. J. 1994. Policy type, bureaucracy, and urban policies: Integrating models of urban service distribution. Policy Studies Journal, 22(1): 87-108.

Lee, I. Y., \& Chang, S. H. 2014. Study on legal issues and candidates' traits of the 6.4 election for superintendent of education. Journal of Law of Education, 26(3): 163-192.

Lin, T. H. 2014. Governing natural disasters: State capacity, democracy, and human vulnerability. Social Forces, 93(3): 1267-1300.

Mann, M. 1986. The sources of social power. Cambridge: Cambridge University Press.

Martin, P. S. 2003. Voting's rewards: Voter turnout, attentive publics, and congressional allocation of federal money. American Journal of Political Science, 47(1): 110-127.

Marwell, N. P. 2004. Privatizing the welfare state: Nonprofit community-based organizations as political actors. American Sociological Review, 69(2): 265-291.

Ministry of Education. 2013. National security management plan for 2014. Retrieved from buseo.sen.go.kr/view/jsp/bbsDownload.jsp?bbsCd=94\&bbsSe$\mathrm{q}=5234$ \&orderNo=1.

Ministry of Education. 2015. Measures to reinforce existing school buildings for 2015 (교육시설과-122). Retrieved from www.open.go.kr/pa/infoWonmun/cateSearch/orginlDetail.do?prdnDt $=20150115091400 \&$ prdnNstRgstNo=DCT5CC85CC82525252514AE2700172FFFFE\&returnUrl=/search/integrate/search. do\#hnp $=0.12936445980110078$.

Ministry of Education. 2016. How special grants are distributed and spent. Retrieved from http://eduinfo.go.kr/portal/pfincBbs/secretYnChk.do?bbsC$\mathrm{d}=\mathrm{FSL} 1005 \&$ seq $=41978$ \&ansTag=N\&currPage=2\&pageSize $=15 \&$ searchWd=.

Ministry of Public Safety and Security. 2015a. Ministry of Public Safety and Security promotes seismic reinforcement against earthquakes. Retrieved from www. mpss.go.kr/home/news/press/press/?boardId=bbs_0000000000000047\&mode $=$ view $\&$ cntId $=660 \&$ category $=\&$ page $I d x=11$.

Ministry of Public Safety and Security. 2015b. Phase 2 (2016-2020) of the master plan for seis- 
mic reinforcement of existing public facilities. Retrieved from www.ndsl.kr/ndsl/ search/detail/report/reportSearchResultDetail.do?cn=TRKO201600016392.

National Emergency Management Agency. 2009. The master plan for seismic reinforcement of existing public facilities. Retrieved from www.nl.go.kr/app/nl/ search/common/download. jsp?file_id=FILE-000085 04065.

Neumayer, E., Plümper, T., \& Barthel, F. 2014. The political economy of natural disaster damage. Global Environmental Change, 24(1): 8-19.

Pallas, A. M., \& Jennings, J. L. 2010. A multiplex theory of urban service distribution: The case of school expenditures. Urban Affairs Review, 45(5): 608-643.

Paul, B. K. 2011. Environmental hazards and disasters: Contexts, perspectives and management. Chichester, UK: Wiley.

Rodriguez-Pose, A., \& Ezcurra, R. 2011. Is fiscal decentralization harmful for economic growth? Evidence from the OECD countries. Journal of Economic Geography, 11(4): 619-643.

Schwab, A. K., Eschelbach, K., \& Brower, D. J. 2007. Hazard mitigation and preparedness. Hoboken, NJ: Wiley.

Shaw, R., \& Kobayashi, M. 2001. Role of schools in creating earthquake-safer environment. OECD workshop, Thesssaloniki.

Seoul Metropolitan Office of Education. 2015a. Midterm seismic reinforcement of school buildings plan (교육시설안전과-4376). Retrieved from www.open.go.kr/ pa/infoWonmun/cateSearch/orginlDetail.do?prdnDt=20150709171400\&prdnNstRgstNo=B10CB151905708448000\&returnUrl=/search/integrate/search. do\#hnp $=0.370601550579839$.

Seoul Metropolitan Office of Education. 2015b. Budgeting for seismic reinforcement of school buildings for emergency shelters (교육시설안전과-5268). Retrieved from www.open.go.kr/pa/infoWonmun/cateSearch/orginlDetail.do? prd$\mathrm{nDt}=20150817113400 \&$ prdnNstRgstNo=B10CB152290822176000\&returnUrl $=/$ search/integrate/search.do\#hnp $=0.9346689475833896$.

Skidmore, M., \& Toya, H. 2013. Natural disaster impacts and fiscal decentralization. Land Economics, 89(1): 101-117.

Board of Audit and Inspection. 2015. School safety management. Retrieved from www.moe.go.kr/boardCnts/fileDown.do? $\mathrm{m}=040103 \& \mathrm{~s}=$ moe \&fileSeq=dca19a456d3d976880d78773fflc1d2d.

Tselios, V., \& Tompkins, E. 2017. Local government, political decentralization and resilience to natural hazard-associated disasters. Environmental Hazards, 16(3): $1-25$.

United Nations Office for Disaster Risk Reduction. 2004. Basic terms of disaster risk reduction. Retrieved from www.unisdr.org/files/7817_7 819isdrterminology11. 
pdf.

Wildavsky, A. B. 1988. Searching for safety. London: Transaction Books.

Wisner, B., Blaikie, P., Cannon, T., \& Davis, I. 2004. At risk: Natural hazards, people's vulnerability, and disasters. New York: Routledge. 